\title{
Vertical movements of shortfin mako sharks Isurus oxyrinchus in the western North Atlantic Ocean are strongly influenced by temperature
}

\author{
Jeremy J. Vaudo \\ Bradley M. Wetherbee \\ Anthony D. Wood \\ Kevin C. Weng \\ Virginia Institute of Marine Science \\ et al
}

Follow this and additional works at: https://scholarworks.wm.edu/vimsarticles

Part of the Aquaculture and Fisheries Commons, and the Marine Biology Commons

\section{Recommended Citation}

Vaudo, Jeremy J.; Wetherbee, Bradley M.; Wood, Anthony D.; Weng, Kevin C.; and et al, Vertical movements of shortfin mako sharks Isurus oxyrinchus in the western North Atlantic Ocean are strongly influenced by temperature (2016). Marine Ecology Progress Series, 547, 163-175.

doi: $10.3354 /$ meps 11646

This Article is brought to you for free and open access by the Virginia Institute of Marine Science at W\&M ScholarWorks. It has been accepted for inclusion in VIMS Articles by an authorized administrator of W\&M ScholarWorks. For more information, please contact scholarworks@wm.edu. 


\title{
Vertical movements of shortfin mako sharks Isurus oxyrinchus in the western North Atlantic Ocean are strongly influenced by temperature
}

\author{
Jeremy J. Vaudo ${ }^{1,2, *}$, Bradley M. Wetherbee ${ }^{1,3}$, Anthony D. Wood ${ }^{4}$, Kevin Weng ${ }^{5}$, \\ Lucy A. Howey-Jordan ${ }^{1}$, Guy M. Harvey ${ }^{1}$, Mahmood S. Shivji ${ }^{1,2}$ \\ ${ }^{1}$ The Guy Harvey Research Institute, Nova Southeastern University, Dania Beach, FL 33004, USA \\ ${ }^{2}$ The Save Our Seas Shark Research Center, Nova Southeastern University, Dania Beach, FL 33004, USA \\ ${ }^{3}$ Department of Biological Sciences, University of Rhode Island, Kingston, RI 02881, USA \\ ${ }^{4}$ Graduate School of Oceanography, University of Rhode Island, Kingston, RI 02881, USA \\ ${ }^{5}$ Fisheries Science, Virginia Institute of Marine Science, College of William \& Mary, Gloucester Point, VA 23062, USA
}

\begin{abstract}
Although shortfin mako sharks Isurus oxyrinchus are regularly encountered in pelagic fisheries, limited information is available on their vertical distribution and is primarily restricted to cooler areas of their geographic range. We investigated the vertical movements of mako sharks across differing temperature regimes within the western North Atlantic by tagging 8 individuals with pop-up satellite archival tags off the northeastern United States and the Yucatan Peninsula, Mexico. Depth and temperature records across $587 \mathrm{~d}$ showed vertical movements strongly associated with ocean temperature. Temperatures $<15^{\circ} \mathrm{C}$ created a lower depth limit to most diving behaviors, and shifts in depths used coincided with changes in the thermal properties of the vertical habitat. In the warmest water columns, sharks spent $36 \%$ of the daytime at depths $>150 \mathrm{~m}$ compared to only $1 \%$ in the coldest water columns. The sharks showed diel diving behavior, with deeper dives occurring primarily during the daytime (maximum depth: $866 \mathrm{~m}$ ). Overall, sharks experienced temperatures between 5.2 and $31.1^{\circ} \mathrm{C}$. When the opportunity was available, sharks spent considerable time in waters ranging from 22 to $27^{\circ} \mathrm{C}$, indicating underestimation of the previously reported upper limit of the mako sharks' preferred temperature. The preference for higher temperatures does not support endothermy as an adaption for niche expansion in mako sharks. The strong influence of thermal habitat on movement behavior suggests potentially strong impacts of rising ocean temperatures on the ecology of this highly migratory top predator.
\end{abstract}

KEY WORDS: Habitat use · Satellite tracking · Dive behavior · Telemetry

\section{INTRODUCTION}

Large sharks are often highly mobile predators that occupy upper or even apex trophic levels (Cortés 1999), and potentially play an important role in the functioning of marine ecosystems (Heithaus et al. 2008,2010 ). In addition, many populations of large shark species have experienced substantial fisherydriven declines (e.g. Musick et al. 1993, Baum et al. 2003, Ferretti et al. 2010, Dulvy et al. 2014), which could, therefore, alter system dynamics (Heithaus et al. 2008). Knowledge of the movements and habitat use of large sharks is imperative for understanding not only their ecological interactions but also for implementing the most effective fisheries management and conservation efforts.

The 3-dimensional habitat of marine ecosystems allows for combinations of vertical and horizontal movements, but most studies of shark space use have focused on the horizontal component (Speed et al. 2010). Assessing vertical movements is equally important from an ecological perspective because it 
provides insights into habitat use, habitat partitioning (e.g. Musyl et al. 2011), species interactions, and connectivity between vertical ecosystems (e.g. epipelagic, mesopelagic, and bathypelagic zones; Frid et al. 2009, Thorrold et al. 2014). Elucidating vertical habitat use patterns of large sharks also reveals their potential interactions with diverse fisheries that use different gear types and deployment depths (e.g. Goodyear et al. 2008, Beverly et al. 2009).

Shortfin mako sharks Isurus oxyrinchus (hereafter, mako sharks) are large sharks found in tropical and temperate waters around the world and are typically associated with pelagic waters, although in some areas they seasonally move onto the continental shelf (Casey \& Kohler 1992). Mako sharks are active predators that hunt large and fast-moving prey such as other sharks, tunas, and billfishes (Cliff et al. 1990, Maia et al. 2006, Wood et al. 2009). They can also exert a large influence on specific prey species. For example, off the northeastern US coast, the impact of mako shark predation on the population of bluefish Pomatomus saltatrix, an important fishery species, may exceed the biomass taken by the fishery itself ( 12 000 t in 2002; Wood et al. 2009). Although mako sharks are largely bycatch in commercial pelagic fisheries, they are nearly always retained because of the high market value for their meat (Casey \& Kohler 1992, Campana et al. 2005); as a further indication of their high exploitation, mako sharks made up the second highest proportion of sharks in the international fin trade in 2000 (Clarke et al. 2006). Mako sharks are also highly prized game fish. Such commercial and recreational harvesting has led to population declines (e.g. Baum et al. 2003, Campana et al. 2005, Baum \& Blanchard 2010), resulting in the categorization of mako sharks as globally Vulnerable by the IUCN Red List (Cailliet et al. 2009).

Despite the mako shark's global distribution and concern about its conservation status, surprisingly little is known about the movement ecology of this species. Seasonal horizontal movements have been documented in some parts of its range. In the eastern North Pacific Ocean, tracking with satellite-linked tags has shown that latitudinal movements are associated with seasonal changes in water temperature and productivity (Block et al. 2011). In the southeastern Indian Ocean, Rogers et al. (2015) observed seasonal northward latitudinal movements by a portion of their satellite-tagged mako sharks. In the western North Atlantic Ocean, information on horizontal movements is based almost entirely on fishery catches and conventional tagging-recapture records, which also suggest temperature-driven horizontal movements. It is known, for example, that mako sharks arrive on the continental shelf off the northeastern coasts of the USA and Canada as water temperature increases in the summer; it has been hypothesized that mako sharks then move southward to overwinter in the warm waters of the Sargasso Sea (Casey \& Kohler 1992).

Studies of mako shark movements have been limited because of the logistic complications imposed by their oceanic nature, their large-scale horizontal movements, and limits in tracking technology. Until recently, information about vertical movements was limited to acoustic telemetry studies, which provided high temporal resolution data, but were short in duration (typically less than $24 \mathrm{~h}$; Holts \& Bedford 1993, Klimley et al. 2002, Sepulveda et al. 2004). Overall, these studies suggested that mako sharks made limited vertical movements and occupied primarily nearsurface waters, making occasional deeper dives below the thermocline during the daytime. More recently, pop-up satellite archival tags have been used to examine mako shark movements, and have revealed generally similar depth and temperature use as suggested by acoustic studies, although with even deeper daytime dives (e.g. Vetter et al. 2008, Stevens et al. 2010, Abascal et al. 2011, Musyl et al. 2011). However, with one exception (see below), all satellite tag studies on mako sharks have focused on the Pacific and Indian Oceans, primarily in the cooler waters of their distribution. Essentially, no detailed, longer-term evaluation of mako continuous movements exists for the Atlantic. In the single Atlantic mako shark satellite telemetry study reported thus far (Loefer et al. 2005), one mako shark tracked for $60 \mathrm{~d}$ using a pop-up archival tag in the warm waters of the Gulf Stream exhibited greater mean depths than mako sharks tracked in the cooler Pacific areas, suggesting that vertical habitat utilization may differ among regions.

Here, we investigated the detailed, longer-term, continuous movements of mako sharks tracked with pop-up satellite archival tags in 2 different regions: the western North Atlantic Ocean off the coast of the northeastern USA and the Gulf of Mexico. These regions differ in their thermal characteristics, and the waters of the Gulf of Mexico are warmer than any other location mako sharks have been tracked thus far. We focus on vertical movements, but include these in the context of horizontal movements where longer-term horizontal tracks were available. Our goals were to (1) describe mako shark depth and temperature habitat use, (2) compare patterns of vertical habitat use across areas with different thermal characteristics, and (3) investigate environmental factors influencing vertical movements of mako sharks. 


\section{MATERIALS AND METHODS}

\section{Shark tagging}

Six mako sharks were tagged off the northeastern USA between Long Island, New York, and Martha's Vineyard, Massachusetts, between 2004 and 2008, and 2 mako sharks were tagged off Isla Mujeres, Mexico, in 2012. Sharks were tagged with pop-up satellite archival tags after being captured via rod and reel, and in most cases $(n=6)$ secured alongside the fishing boat. Secured sharks were measured (fork length) and sexed. The 2 sharks that were not secured (Sharks 6 and 8; Table 1) were tagged with a tagging pole, and their sizes were estimated.

Four sharks were tagged with Mk10-PAT tags (175 mm long $\times 40 \mathrm{~mm}$ wide; Wildlife Computers), and 4 sharks were tagged with PTT-100 tags $(166 \times$ $41 \mathrm{~mm}$; Microwave Telemetry; Table 1). Mk10-PAT tags were attached using stainless steel M-barbs, whereas PTT-100 tags were attached using an umbrella dart. Darts were anchored into the shark's dorsal musculature lateral to or at the rear of the first dorsal fin.

Mk10-PAT tags recorded and archived depth $( \pm 0.5 \mathrm{~m})$, temperature $\left( \pm 0.05^{\circ} \mathrm{C}\right)$, and light levels at 2 min intervals and were programmed to detach from the shark after periods ranging from 60 to $90 \mathrm{~d}$. Once detached, Mk10-PAT tags transmitted summaries of the archived raw data via satellite uplink. Archived data were summarized as histograms of $2 \mathrm{~h}$ bin intervals for satellite transmission. Because depth and temperature bins for Sharks 1 and 2 differed from
Sharks 3 and 4, individual bins were combined to create new bins common to all tags. The resulting depth bins were 0-10, 10.5-50, 50.5-100, 100.5-150, 150.5-500, and 500.5-1000 $\mathrm{m}$. The new temperature bins were $<5,5.05-20,20.05-25$, and $>25^{\circ} \mathrm{C}$. The PTT-100 tags recorded and archived depth $( \pm 5.4 \mathrm{~m})$, temperature $\left( \pm 0.23^{\circ} \mathrm{C}\right)$, and light levels at $15 \mathrm{~min}$ intervals for the first 4 mo of deployment. Because of data storage limits, after this period the tags began recording data at $30 \mathrm{~min}$ intervals, overwriting the data stored at 15 min intervals. These tags were programmed to detach from the sharks after periods ranging from 4 to 6 mo. Once detached, PTT-100 tags transmitted the archived raw data via satellite uplink. Because of limits in battery life and satellite coverage, typically only a subset of the archived data was successfully transmitted. Although the PTT-100 tags operated at lower temporal resolution than Mk10-PAT tags, the large data sets produced by long track lengths (see 'Results') were considered sufficient for estimating depth distributions (i.e. given enough time and sampling, even ephemeral behaviors should be detected).

\section{Data analysis}

Light data recorded by the tags were used to generate daily geolocation estimates which were then filtered using a Kalman filter state-space model incorporating sea surface temperature ('ukfsst' package, Nielsen et al. 2012) and bathymetry filter ('analyzepsat' package, Galuardi 2012) in R (R Develop-

Table 1. Summary information for shortfin mako sharks Isurus oxyrinchus tracked with pop-up satellite archival tags in the western North Atlantic and the Gulf of Mexico. Last estimated location represents the location of the last day the tag was confirmed to be on the shark via depth data

\begin{tabular}{|c|c|c|c|c|c|c|c|c|}
\hline $\begin{array}{l}\text { Shark } \\
\text { ID }\end{array}$ & Sex & $\begin{array}{c}\text { Fork } \\
\text { length } \\
(\mathrm{cm})\end{array}$ & Tag type & Date tagged & Tagging location & $\begin{array}{c}\text { Days } \\
\text { at } \\
\text { liberty }\end{array}$ & $\begin{array}{l}\text { Last estimated } \\
\text { location }\end{array}$ & $\begin{array}{c}\text { Displacement } \\
\text { distance } \\
(\mathrm{km})\end{array}$ \\
\hline \multicolumn{9}{|c|}{ Northeast USA } \\
\hline 1 & $\mathrm{~F}$ & 130 & MK10-PAT & 18 Aug 2004 & $41.07^{\circ} \mathrm{N}, 70.90^{\circ} \mathrm{W}$ & 20 & $39.53^{\circ} \mathrm{N}, 70.90^{\circ} \mathrm{W}$ & 170 \\
\hline 2 & $\mathrm{~F}$ & 154 & MK10-PAT & 18 Aug 2004 & $41.14^{\circ} \mathrm{N}, 70.92^{\circ} \mathrm{W}$ & 7 & $40.60^{\circ} \mathrm{N}, 71.81^{\circ} \mathrm{W}$ & 96 \\
\hline 3 & M & 150 & MK10-PAT & 31 Jul 2005 & $41.15^{\circ} \mathrm{N}, 71.35^{\circ} \mathrm{W}$ & 7 & $41.06^{\circ} \mathrm{N}, 70.51^{\circ} \mathrm{W}$ & 71 \\
\hline 4 & M & 206 & MK10-PAT & 25 Sep 2005 & $41.46^{\circ} \mathrm{N}, 70.81^{\circ} \mathrm{W}$ & 24 & $42.12^{\circ} \mathrm{N}, 62.92^{\circ} \mathrm{W}$ & 660 \\
\hline 5 & $\mathrm{~F}$ & 190 & РTT-100 & 15 Aug 2007 & $41.07^{\circ} \mathrm{N}, 70.84^{\circ} \mathrm{W}$ & 122 & $23.45^{\circ} \mathrm{N}, 77.20^{\circ} \mathrm{W}$ & 2042 \\
\hline 6 & $?$ & $\sim 245$ & PTT-100 & 1 Sep 2008 & $41.03^{\circ} \mathrm{N}, 71.81^{\circ} \mathrm{W}$ & 181 & $32.43^{\circ} \mathrm{N}, 78.72^{\circ} \mathrm{W}$ & 1137 \\
\hline \multicolumn{9}{|c|}{ Gulf of Mexico } \\
\hline 7 & $\mathrm{M}$ & 183 & PTT-100 & 28 Mar 2012 & $21.43^{\circ} \mathrm{N}, 86.49^{\circ} \mathrm{W}$ & 153 & $28.80^{\circ} \mathrm{N}, 88.06^{\circ} \mathrm{W}$ & 832 \\
\hline 8 & $\mathrm{~F}$ & $\sim 150$ & PTT-100 & 30 Mar 2012 & $21.38^{\circ} \mathrm{N}, 86.49^{\circ} \mathrm{W}$ & 73 & $20.31^{\circ} \mathrm{N}, 95.40^{\circ} \mathrm{W}$ & 934 \\
\hline
\end{tabular}


ment Core Team; Lam et al. 2008) to determine a most probable track for each shark. Sea surface temperature (NOAA CoastWatch Experimental Blended SST: $5 \mathrm{~d}$ composite at $0.1^{\circ} \times 0.1^{\circ}$ resolution) and bathymetry (1 min resolution) data were obtained from NOAA Coastwatch (http://coastwatch.pfeg. noaa.gov). Using times of sunrise and sunset (http:// aa.usno.navy.mil/data) for the locations of the most probable tracks, we organized the $2 \mathrm{~h}$ summary data bins from Mk10-PAT tags and raw data from PTT-100 tags into periods of daytime and nighttime. Bins from Mk10-PAT tags that included either sunrise or sunset (i.e. included both daytime and nighttime periods) were not analyzed.

Because sharks were tagged at different locations and times, and in some cases moved long distances, environmental conditions experienced varied considerably both between and within individual tracks. To account for this environmental variability when comparing vertical and thermal habitat use by the sharks, the days of tracking data with similar temperaturedepth profiles were grouped to form thermal habitats. Temperature-depth profiles were generated from the tags for each day with available data (584 d), as the tags provided a direct measure of conditions experienced by the sharks. The thermal habitats were then created via cluster analysis on the temperature-depth profiles. Because depth use varied from day to day and temperatures were taken at set time intervals rather than set depth intervals, temperature values were missing for many depths in the combined tag data set. To help counter the effects of missing data and make the cluster analysis more robust, maximum temperature, approximate depth at $20^{\circ} \mathrm{C}$, and maximum and minimum temperatures for the following depth ranges: 0-20, 20-50, 50-75, 75-100, 100-125, 125-150, 150-200, 200-250, and 250-300 m, from each profile were also included in the cluster analysis. In addition, temperature profiles based on $<5$ data points were not included in the cluster analysis. Each variable was standardized by subtracting the variable's mean and dividing by the variable's mean absolute deviation. Divisive hierarchical cluster analysis was performed on the matrix of Euclidean distances in R using the 'cluster' package (Maechler et al. 2015). This method handles missing data by calculating pairwise distances for the distance matrix based only on the data categories the pair share in common.

After all the daily temperature-depth profiles had been classified via cluster analysis into thermal habitats, daily attributes associated with shark dive behaviors (i.e. maximum depth, maximum tempera- ture, and minimum temperature) were examined for daytime and nighttime periods using linear mixed models. Diel effects were also examined by examining the differences between daytime and nighttime maximum depths of individual days. Linear mixed models were fit in $\mathrm{R}$ using the 'lme4' package (Bates et al. 2015). Five competing models were fit: a null model with no fixed effects, models with thermal habitat or size as the sole fixed effect, a model with both thermal habitat and size as fixed effects, and a model that included thermal habitat, size, and their interaction as fixed effects. All models included individual shark as a random effect, and size was nested in individual. The best fit model was selected using sequential likelihood ratio tests in order of decreasing model deviance. Pairwise comparisons (Tukey contrasts) for fixed effects were performed using the 'multcomp' package (Hothorn et al. 2008) in R. Prior to analysis, fine-scale depth time-series data from PTT-100 tags were examined for unnatural movements related to post-release stress. There was no indication of unusual post-release movements from these sharks, so the full datasets were used for all sharks (Fig. S1 in the Supplement, www.int-res.com/articles/suppl/ m547p163_supp.pdf). Two days with anomalous depth values were excluded from the analyses. These 2 days from Habitats A and C (see 'Results') were consecutive days from the latter half of Shark 6's track, and featured maximum depths exceeding $745 \mathrm{~m}$, i.e. more than $250 \mathrm{~m}$ deeper than the next deepest maximum depths retcorded in their respective thermal habitats for any shark. The day from Habitat A was also the only day within this thermal habitat for Shark 6 and, therefore, would have had greater leverage than other data points.

\section{RESULTS}

All 4 Mk10-PAT tags (Sharks 1 to 4) prematurely released from the sharks, providing depth and temperature data for 7 to $24 \mathrm{~d}$ (25 to 150 depth histograms [ $2 \mathrm{~h}$ bins]; 19 to 140 temperature histograms [2 h bins]). Three PTT-100 tags (Sharks 5 to 7 ) detached as scheduled, and 1 PTT-100 tag (Shark 8) detached prematurely. The PTT-100 tags provided depth and temperature data for 73 to $181 \mathrm{~d}$ (6921 to 9813 depth readings; 6849 to 9813 temperature readings; Table 1). Time-series data from PTT-100 tags indicated that these sharks exhibited bounce diving for the duration of their tracks. Overall, sharks experienced maximum temperatures ranging from 23.3 to 
$31.1^{\circ} \mathrm{C}$, minimum temperatures from 5.2 to $11.8^{\circ} \mathrm{C}$, and maximum depths ranging from 28 to $866 \mathrm{~m}$.

Sharks 1, 2, and 3, which were only tracked for 7 to $20 \mathrm{~d}$, showed limited displacement (straight line distance between tagging and final locations; Table 1) and typically remained over the continental shelf during tag deployment (Fig. 1), although depth data suggested forays into deeper waters off the shelf. During its $24 \mathrm{~d}$ track, Shark 4, tagged at the end of September, moved off the shelf into waters east of Georges Bank for a displacement of $660 \mathrm{~km}$ (Fig. 1). Sharks 5 and 6, tagged in the late summer and tracked for 4 and 6 mo, respectively, left the region of the continental shelf during the autumn when sea surface temperatures dropped below $\sim 15^{\circ} \mathrm{C}$, and

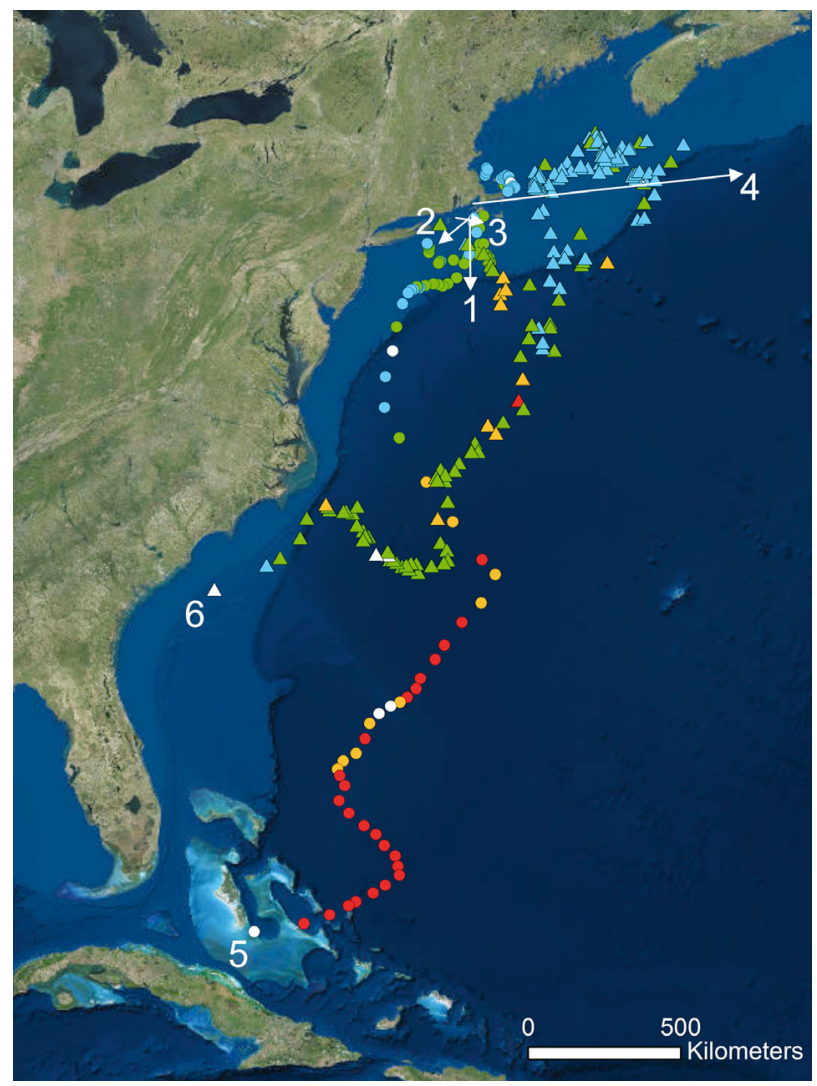

Fig. 1. Horizontal movements of shortfin mako sharks Isurus oxyrinchus tagged off the northeastern USA. All sharks were tagged in the same general area. Displacements of Sharks 1 to 4 carrying Mk-10 PAT tags are shown with a vector indicating direction of movement. Daily locations of the most probable tracks and popup locations (white symbol accompanied by shark ID number) of Sharks 5 (circles) and 6 (triangles) carrying PTT-100 tags are also shown. Colors for Sharks 5 and 6 represent thermal habitats, from warmest to coldest: A (red), B (orange), C (green), and D (blue). Data were insufficient to categorize white locations into thermal habitats. See 'Results' for detailed descriptions of the thermal habitats. Base map from ESRI (http://goto.arcgisonline.com/maps/World_Imagery) made long-distance southerly movements, through mainly pelagic waters. These movements resulted in displacements of 2042 and $1137 \mathrm{~km}$ (Table 1, Fig. 1). The 2 sharks (Sharks 7 and 8) tagged at the mouth of the Gulf of Mexico moved primarily over deep waters ( $>1000 \mathrm{~m}$ ) throughout the duration of their tracks (Fig. 2). After release, both of these sharks traveled northeast into the deeper waters between the Campeche Bank and West Florida Shelf, where they remained for up to $31 \mathrm{~d}$. Upon leaving this area, the sharks made largely directed, long-distance movements in different directions: Shark 7 to the northern Gulf of Mexico (displacement of $832 \mathrm{~km}$ ) and Shark 8 to the southwestern Gulf of Mexico (displacement of $934 \mathrm{~km})$.

Cluster analysis revealed that the 573 daily temperature-depth profiles with at least 5 data points separated into 4 broad thermal habitats (Fig. 3a). Hereafter, these 4 habitats are referred to alphabetically in terms of their overall temperature profiles from warmest (Habitat A) to coldest (Habitat D). The mean temperature-depth profile of Habitat A had a surface temperature of $26.5^{\circ} \mathrm{C}$. Temperature gradually decreased with depth at a fairly constant rate reaching $18^{\circ} \mathrm{C}$ at $\sim 250 \mathrm{~m}$. Habitat $\mathrm{B}$ also had a high mean surface temperature $\left(26.0^{\circ} \mathrm{C}\right)$, but temperature decreased much more quickly with depth. By $\sim 125 \mathrm{~m}$, mean temperature reached $18^{\circ} \mathrm{C}$. Temperatures in Habitat $\mathrm{C}$ decreased at a similar rate as Habitat $B$, but mean surface temperature was cooler $\left(20.9^{\circ} \mathrm{C}\right)$. Habitat D was not only much cooler than the other groups (mean surface temperature: $16.1^{\circ} \mathrm{C}$ ), but was less variable with regard to temperature. Mean temperature-depth profiles of Habitats $\mathrm{C}$ and D converged at $\sim 130 \mathrm{~m}$ (Fig. 3b). There was no indication of a clear thermocline in any of the thermal habitats; although individual days within each thermal habitat may have distinct thermoclines, they were rare (Fig S2 in the Supplement at www.int-res. com/articles/suppl/m547p163_supp.pdf).

Daily depth-temperature profiles of the sharks tagged off the northeastern USA predominantly clustered into Habitats C and D (the colder habitats). Only $13 \%$ of daily profiles from these sharks clustered into Habitats A and B (the warmer habitats), with all of these profiles belonging to the 2 sharks (Sharks 5 and 6) that traveled south in the autumn (Table 2). For these sharks, temperature profiles clustering in the warmer habitats were primarily from offshore locations south of $35^{\circ} \mathrm{N}$ latitude (i.e. in the warmer waters south of the Gulf Stream). Conversely, sharks tagged at the mouth of the Gulf of Mexico (Sharks 7 and 8) remained in the tropical and 


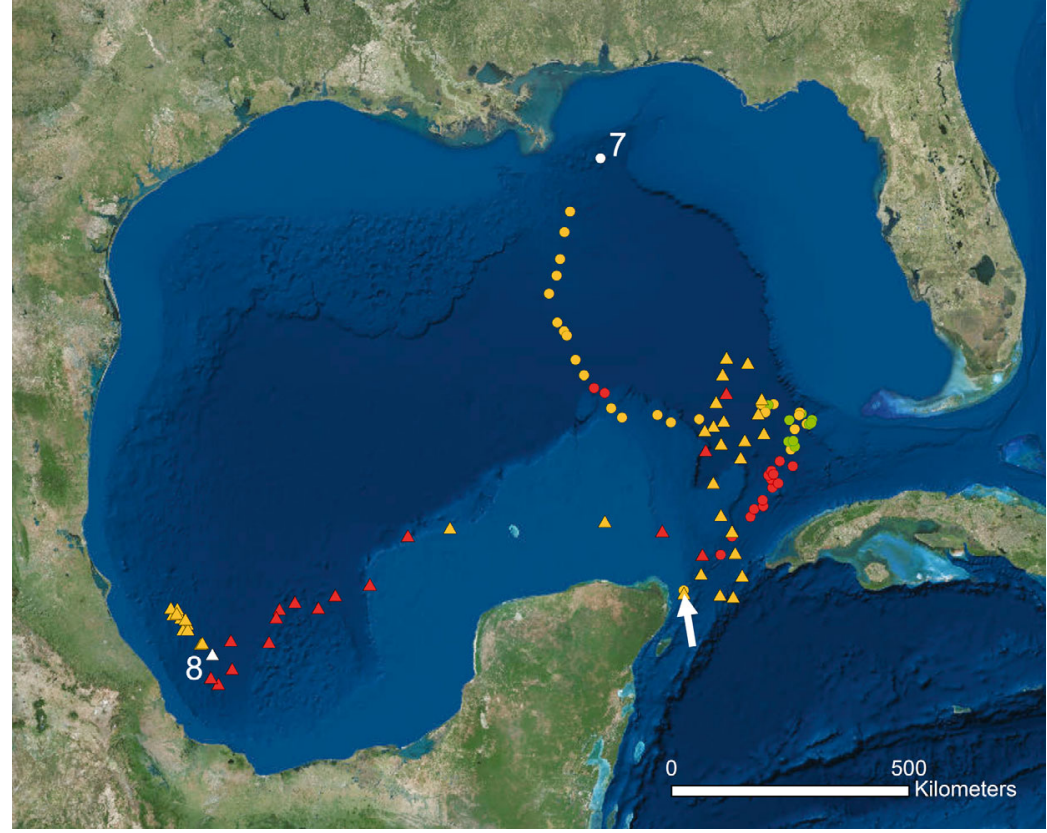

Fig. 2. Horizontal movements of shortfin mako sharks Isurus oxyrinchus in the Gulf of Mexico. The white arrow indicates the tagging location of both sharks. Daily locations of the most probable tracks and popup locations (white symbol accompanied by shark ID number) of Sharks 7 (circles) and 8 (triangles) carrying PTT-100 tags are shown. Colors for Sharks 7 and 8 represent thermal habitats; details as in Fig. 1

subtropical waters of the Gulf of Mexico, and $93 \%$ of their temperature-depth profiles of clustered in the warmer thermal habitats (Table 2).

Vertical habitat use by the sharks differed among thermal habitats. Time spent at depths $>150 \mathrm{~m}$ decreased with decreasing water temperature (Fig. 4). While occupying the warmest water columns (Habi- tat A), sharks spent $36 \%$ of the daytime below $150 \mathrm{~m}_{i}$ in contrast, $<1 \%$ of daytime depths exceeded $150 \mathrm{~m}$ in the coolest water columns (Habitat D). This pattern in depth use by the sharks also held during the nighttime (Fig. 4). Overall, sharks spent less time at depth during the nighttime (Fig. 4).

Daytime maximum depths typically exceeded nighttime maximum depths. Shark size and thermal habitat influenced daytime and nighttime maximum depths (Table 3), with maximum daytime and nighttime depths increasing with shark size and warmer habitats (Fig. 5 and see Table S1 in the Supplement at www.int-res.com/ articles/suppl/m547p163_supp.pdf), and did not appear to be restricted by bathymetric constraints (i.e. sharks did not use the whole water column). Furthermore, the difference between daytime and nighttime maximum depths was also dependent on shark size and thermal habitat (Table 3); depth differences increased with increasing shark size, and there were larger depth differences in warmer thermal habitats (Habitats A and B) than in cooler thermal habitats (Habitats C and D; Fig. 6, Table S1). There was also evidence that temperature influenced the upper end of mako shark depth distributions. Both mako sharks tracked in the Gulf of Mexico spent a great deal of their tracks avoiding warm surface waters (Fig. S3 in the Supple-
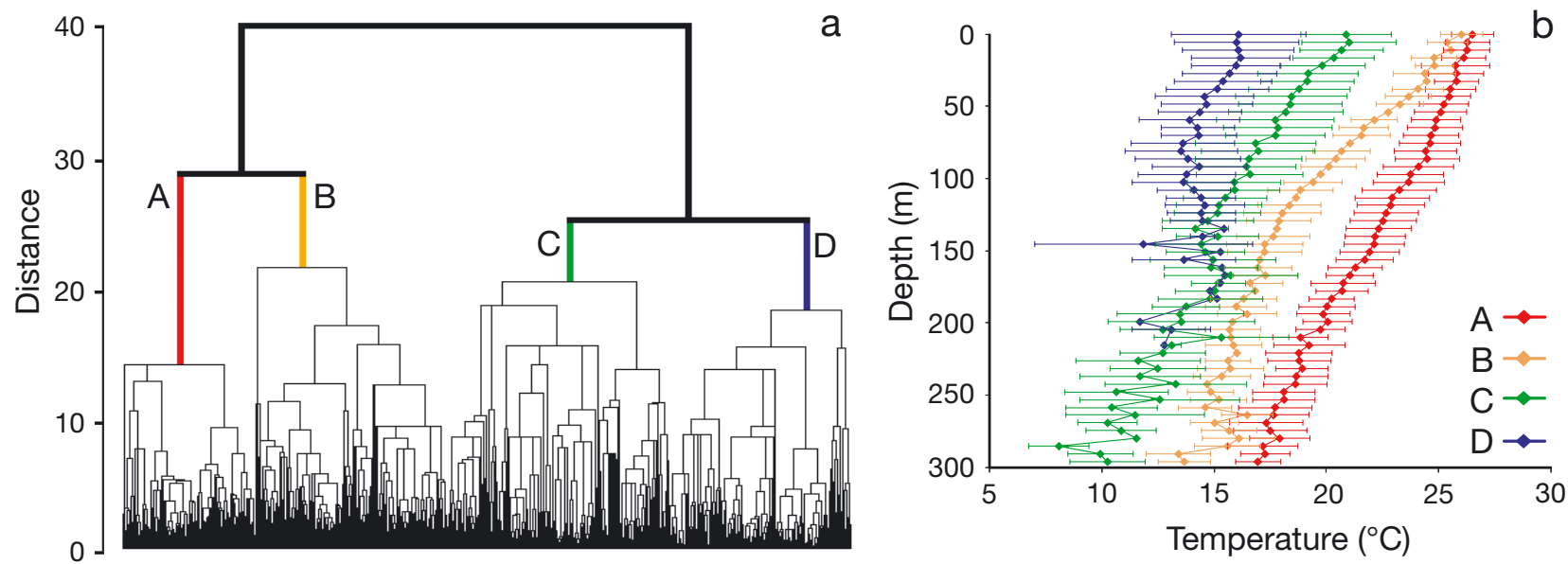

Fig. 3. (a) Clustering of temperature-depth profiles showing the 4 thermal habitats (Habitats A-D; see 'Results' for details of the habitats) used for comparative movement analyses of shortfin mako sharks Isurus oxyrinchus. (b) Mean temperaturedepth profiles $( \pm \mathrm{SD})$ of the 4 thermal habitats 
Table 2. Number of days that tagged shortfin mako sharks Isurus oxyrinchus were recorded in each thermal habitat, where A is the warmest and D is the coolest. See 'Results' for a detailed description of the 4 thermal habitats

\begin{tabular}{|lcccc|}
\hline Shark ID & A & B & C & D \\
\hline Northeast USA & & & & \\
1 & 0 & 0 & 14 & 5 \\
2 & 0 & 0 & 6 & 0 \\
3 & 0 & 0 & 1 & 2 \\
4 & 0 & 0 & 9 & 15 \\
5 & 24 & 10 & 42 & 42 \\
6 & 1 & 11 & 81 & 85 \\
Gulf of Mexico & & & & \\
7 & 55 & 82 & 15 & 0 \\
8 & 24 & 49 & 0 & 0 \\
\hline
\end{tabular}

ment). These sharks spent a smaller proportion of the nighttime (9.75 and $5.8 \%$ ) within the upper $30 \mathrm{~m}$ of the water column in Habitat $\mathrm{A}$ than in the cooler Habitat B (11.7 and $19.6 \%$, respectively).

Similarly, temperatures occupied by the sharks differed among thermal habitats. Not surprisingly, use of waters $>25^{\circ} \mathrm{C}$ decreased and use of waters $<20^{\circ} \mathrm{C}$ increased as water column conditions cooled because warmer waters were not available (Fig. 7). In Habitat A (warmest), sharks spent $33 \%$ of the daytime in waters $>25^{\circ} \mathrm{C}$ i in contrast, $7 \%$ of the time in Habitat D (coldest) was spent at temperatures $>20^{\circ} \mathrm{C}$. At the lower end of the scale, $27 \%$ of daytime temperature values from Habitat A were 20 to $25^{\circ} \mathrm{C}$, compared to $93 \%$ of daytime values from Habitat D water columns. Except for in Habitat D, sharks spent more time during the night in waters $>20^{\circ} \mathrm{C}$ than during the daytime (Fig. 7).

Maximum temperatures for day$B$ time and nighttime periods were influenced by size and habitat (Table 3). Not surprisingly, maximum temperatures increased with warming habitats; larger sharks also tended to have lower maximum temperatures (Fig. 8, Table S1). The effect of size on daytime minimum temperatures differed with thermal habitat (Table 3). Larger sharks encountered higher minimum daytime temperatures in thermal Habitat A, while they experienced lower minimum daytime temperatures in Habitats $B$ and C (Figs. 8 \& 9, Table S1). Nighttime minimum temperatures did not vary with size, but were related to thermal habitat (Table 3), with higher minimum temperatures in warmer habitats (Fig. 9, Table S1).

Fig. 4. Daytime and nighttime depth distributions (weighted mean $\pm \mathrm{SD}$ ) of shortfin mako sharks Isurus oxyrinchus in the 4 thermal habitats (temperatures decrease from A to D; see 'Results' for details). Values were weighted by the number of hours each shark was associated with each thermal habitat

Table 3. Model deviances for all models tested for each of the 7 dependent variables examined. All models also included individual sharks as a random effect. Values in bold correspond to the best fit model. Any further reductions in deviance beyond the bold values are not statistically significant. $D_{\max }$ : maximum depth, $T_{\max }\left(T_{\min }\right)$ : maximum (minimum) temperature

\begin{tabular}{|lcccccccc|}
\hline Model & df & $\begin{array}{c}\text { Diff. between } \\
\text { day and night }\end{array}$ & $\begin{array}{c}\text { Daytime } \\
\mathrm{D}_{\max }\end{array}$ & $\begin{array}{c}\text { Nighttime } \\
\mathrm{D}_{\max }\end{array}$ & $\begin{array}{c}\text { Daytime } \\
\mathrm{D}_{\max }\end{array}$ & $\begin{array}{c}\text { Nighttime } \\
\mathrm{T}_{\max }\end{array}$ & $\begin{array}{c}\text { Daytime } \\
\mathrm{T}_{\min }\end{array}$ & $\begin{array}{c}\text { Nighttime } \\
\mathrm{T}_{\min }\end{array}$ \\
\hline Null (intercept only) & 11 & 6335.7 & 6510.1 & 6150.2 & 2583.6 & 2321.4 & 2838.0 & 2544.7 \\
Size & 12 & 6324.1 & 6495.0 & 6071.3 & 2564.7 & 2306.5 & 2820.7 & 2536.6 \\
Thermal habitat & 15 & 6319.8 & 6487.8 & 6063.3 & 2526.5 & 2260.6 & 2785.9 & $\mathbf{2 5 0 0 . 2}$ \\
Size + Thermal habitat & 16 & $\mathbf{6 3 1 4 . 0}$ & $\mathbf{6 4 7 5 . 8}$ & $\mathbf{6 0 5 3 . 3}$ & $\mathbf{2 5 1 2 . 1}$ & $\mathbf{2 2 5 6 . 5}$ & 2783.3 & 2499.1 \\
Size $\times$ Thermal habitat & 19 & 6307.7 & 6474.3 & 6048.9 & 2507.4 & 2249.4 & $\mathbf{2 7 7 4 . 8}$ & 2497.7 \\
\hline
\end{tabular}




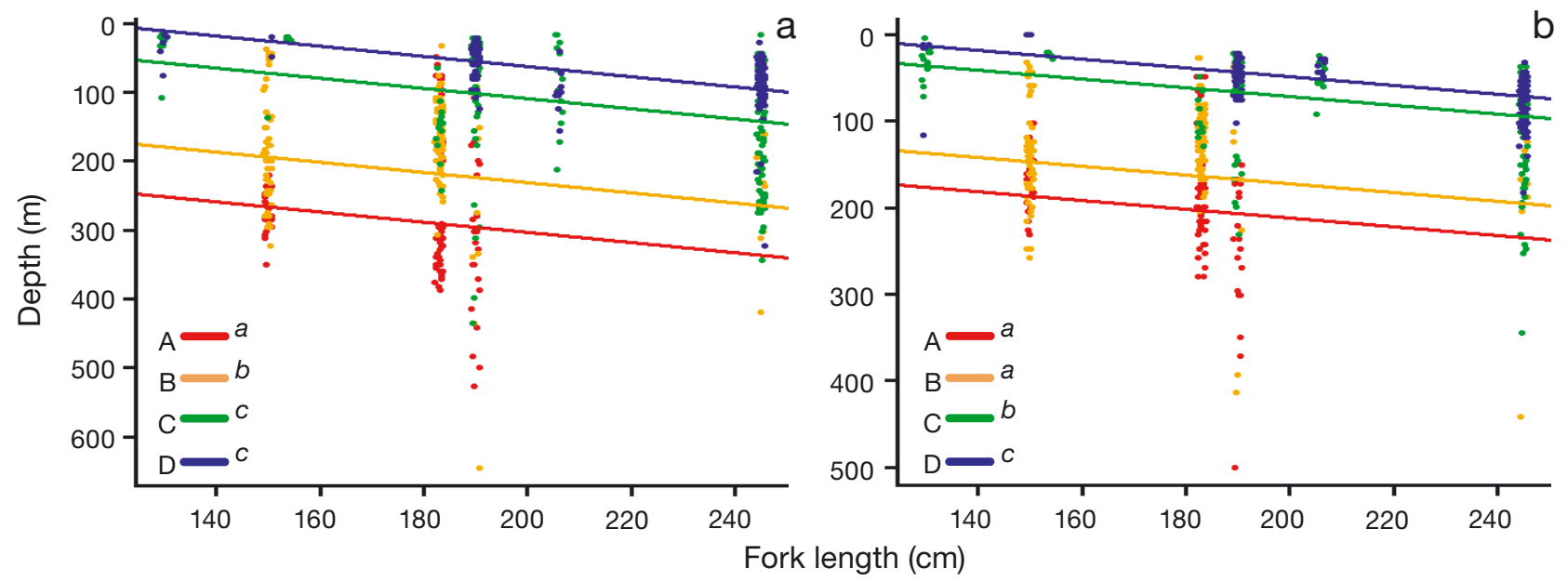

Fig. 5. Daily daytime (a) and nighttime (b) maximum depths of shortfin mako sharks Isurus oxyrinchus. Habitats with the same lowercase letters are not statistically different. Data points from individual sharks are offset for clarity

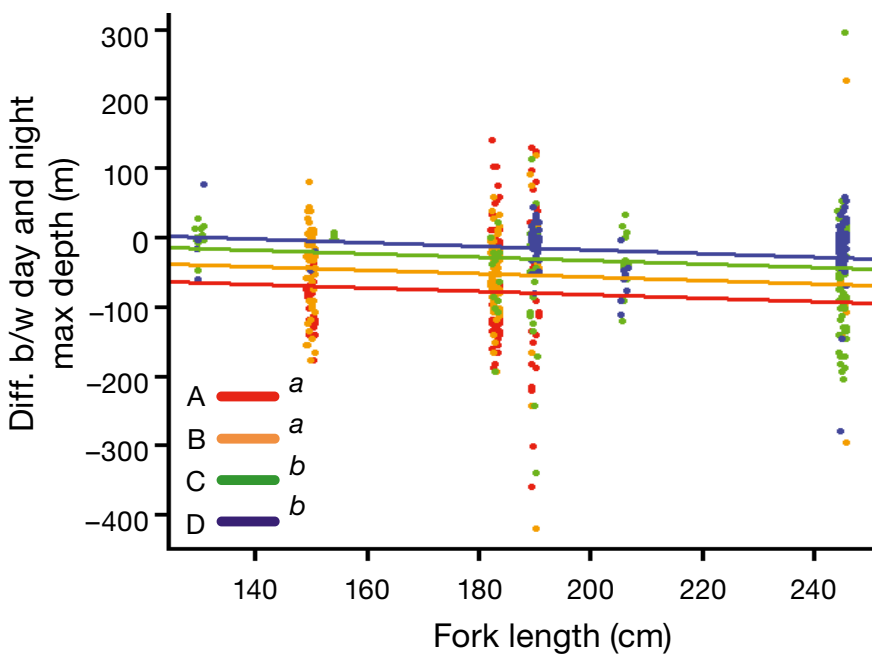

Fig. 6. Differences between daytime and nighttime maximum depths of shortfin mako sharks Isurus oxyrinchus. Negative values indicate deeper daytime values, while positive values indicate deeper nighttime values. Habitats with the same lowercase letters are not statistically different. Data points from individual sharks are offset for clarity

\section{DISCUSSION}

Mako shark movements demonstrated a strong association with temperature in the western North Atlantic Ocean and Gulf of Mexico, 2 regions with differing thermal characteristics. Although sample sizes were limited and track durations were highly variable, commonalties existed, suggesting the generality of temperature as a driving force in at least the vertical behavior of this widely exploited species.

Short track durations and small sample sizes precluded a detailed analysis of horizontal movements, although there was some indication that temperature may have influenced mako shark horizontal movements in the western North Atlantic (i.e. off the northeastern USA). In this region, the 2 sharks tracked for several months showed no obvious directional patterns, until November and December, when sea surface temperatures dropped below $\sim 15^{\circ} \mathrm{C}$. The southerly movements made by these sharks were consistent with the hypothesized mako shark migration in the western North Atlantic proposed by Casey $\&$ Kohler (1992) on the basis of catch records and conventional mark-recapture tag returns. Similar seasonal horizontal movements from cooler to warmer waters have also been observed in mako sharks in the northeastern (Block et al. 2011) and southeastern Pacific Ocean (Abascal et al. 2011), and partially in the southeastern Indian Ocean (Rogers et al. 2015). In contrast, mako sharks in the Gulf of Mexico, which did not experience large drops in sea surface temperatures over the course of their tracks, showed no clear directional patterns, although these tracks, conducted during the spring and summer, concluded before any possible seasonal migrations may have occurred.

Temperature also appeared to drive the variability observed in vertical habitat use within and among individual sharks, with depth distribution and diving behavior differing with water column thermal characteristics. Even in the shallow shelf waters off the northeastern USA, temperature appeared to play a dominant role in depth distribution as mako sharks did not commonly make use of the whole water column. This behavior does not appear to be a result of avoidance of demersal habitats because mako sharks are known to occasionally feed on demersal species (Maia et al. 2006, Wood et al. 2009, Preti et al. 2012). 


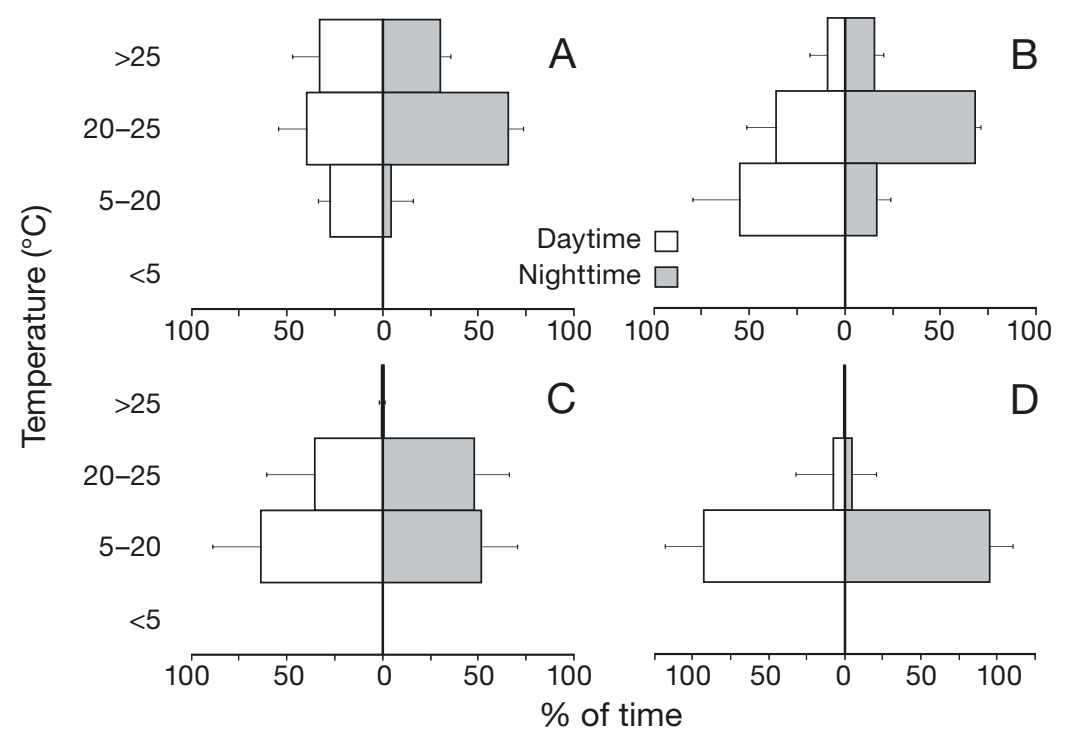

Fig. 7. Daytime and nighttime temperature distributions (weighted mean \pm $\mathrm{SD}$ ) of shortfin mako sharks Isurus oxyrinchus in the 4 thermal habitats (temperatures decrease from A to $D_{\text {; }}$ see 'Results' for details). Values were weighted by the number of hours each shark contributed to each thermal habitat. Note: The $x$-axis of Habitat D is on a different scale waters of the California Current (Vetter et al. 2008).

Overall, the lower boundary of the depth range was generally limited to depths with temperatures $\sim 10$ to $15^{\circ} \mathrm{C}$, which is similar to that observed for mako sharks in the eastern Pacific Ocean (Vetter et al. 2008). Adjustment of maximum depths used, however, does not appear to be the only way mako sharks responded to temperature changes. For example, in the Gulf of Mexico, where water column temperatures were consistently high, surface temperatures regularly in excess of $\sim 28^{\circ} \mathrm{C}$ were associated with sharks using deeper minimum depths (i.e. sharks generally avoided warm surface waters). Such submergence in the presence of warm surface waters has also been observed in several confamilial regional endotherms, viz. salmon shark Lamna ditropis (Weng et al. 2005) and porbeagle shark L. nasus

Overall, the use of cooler bodies of water (i.e. Habitats $\mathrm{C}$ and $\mathrm{D}$ ) was accompanied by a narrow distribution of shallow depths. Conversely, in warmer bodies of water (i.e. Habitats A and B), the range of depths used during both the daytime and nighttime expanded, with greater depths used overall. Temperature-mediated increases in mako shark depth distributions have been observed in a mako shark that crossed the boundary of the North Pacific Transition Zone in the central Pacific Ocean (Musyl et al. 2011) and in mako sharks using inshore and offshore
(Campana et al. 2010), but also in the ectothermic blue shark Prionace glauca (Campana et al. 2011).

Oxygen concentrations have also been suggested to influence the maximum depth limit of active pelagic fishes (Prince \& Goodyear 2006, Braun et al. 2015), including mako sharks. In the southeastern Pacific Ocean, mako shark dives often terminated at depths consistent with an oxygen concentration of $3 \mathrm{ml} \mathrm{l}^{-1}$ (Abascal et al. 2011), and off California, mako sharks rarely descended to depths with oxygen concentrations $<2 \mathrm{ml} \mathrm{l}^{-1}$ (Vetter et al. 2008). Off the At-

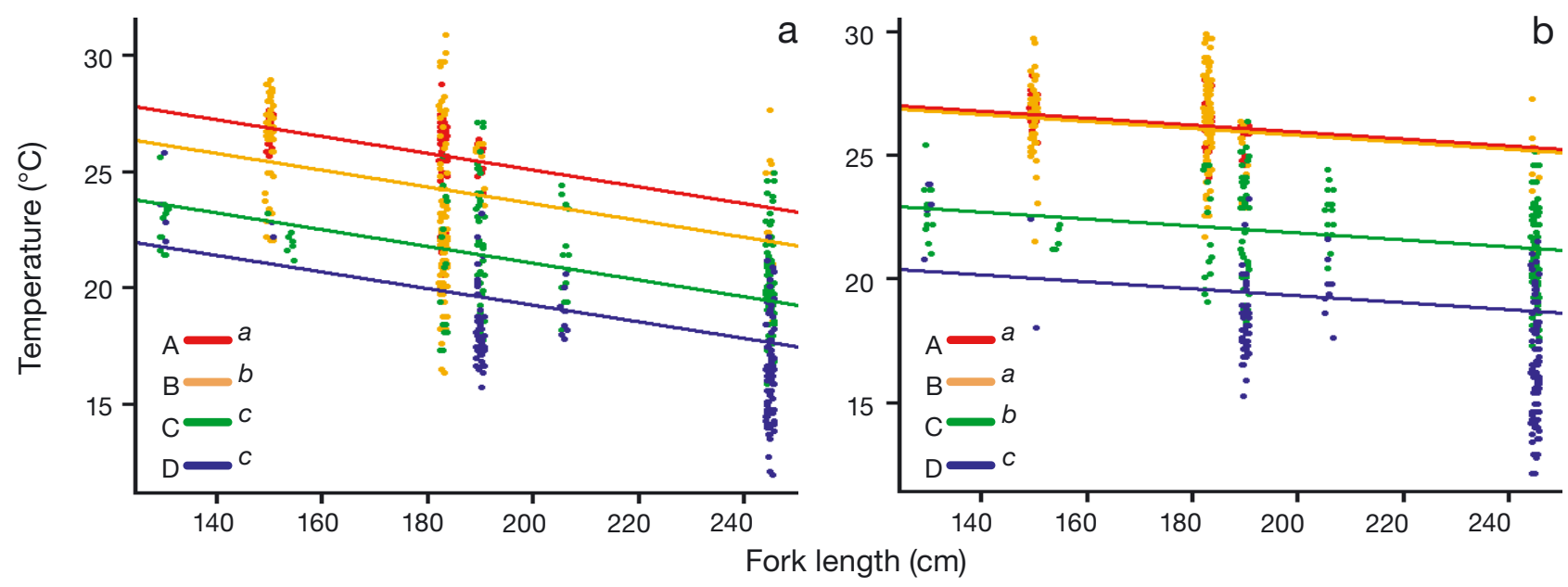

Fig. 8. Daily (a) daytime and (b) nighttime maximum temperature of shortfin mako sharks Isurus oxyrinchus. Habitats with the same lowercase letters are not statistically different. Data points from individual sharks are offset for clarity 

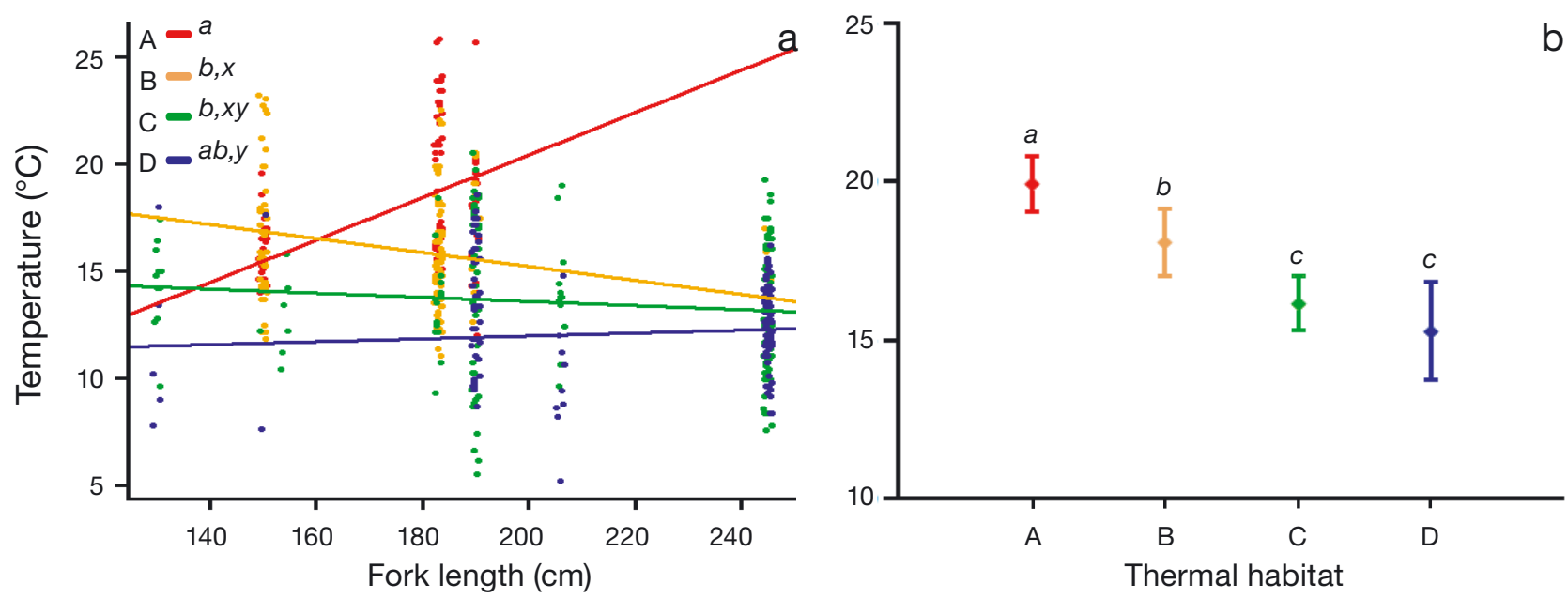

Fig. 9. Daily (a) daytime and (b) nighttime minimum temperature of shortfin mako sharks Isurus oxyrinchus. Habitats with the same lowercase letters are not statistically different. In panel (a), $a$ and $b$ refer to the slopes of the lines and $x$ and $y$ refer to the $y$ intercepts of lines with statistically indistinguishable slopes. Data points from individual sharks are offset for clarity in panel (a). In panel (b), error bars represent $95 \%$ confidence intervals

lantic coast of the USA, oxygen concentrations are above $3 \mathrm{ml} \mathrm{l}^{-1}$ throughout the depth range that we observed mako sharks using (Garcia et al. 2014). In the Gulf of Mexico, sharks often reached depths with oxygen concentrations between 2.5 and $3 \mathrm{ml} \mathrm{l}^{-1}$ (Garcia et al. 2014) when those depths coincided with temperatures of $\sim 15^{\circ} \mathrm{C}$, but typically terminated dives at higher oxygen concentrations if the $\sim 15^{\circ} \mathrm{C}$ temperature threshold was reached. Therefore, oxygen concentration did not appear to be a factor influencing the depth distribution of mako sharks in our study, suggesting the hypothesis that temperature may be the overriding driver of vertical distribution in the western North Atlantic Ocean in general.

Although water temperature appeared to set the boundaries of the portion of the water column used by mako sharks, light levels were associated with how that range of depths was used. Mako sharks displayed clear diel shifts in their depth distributions, with deeper depths used during the daytime than nighttime. Diel shifts in vertical habitat use (i.e. deeper during the daytime) is common among pelagic fish predators (e.g. Walli et al. 2009, Schaefer \& Fuller 2010, Dewar et al. 2011) and is often attributed to following the vertical migrations of prey, possibly within the deep scattering layer. Diet data, however, show that although mako sharks consume some species associated with the deep scattering layer, these prey items comprise a small proportion of the diet (Stillwell \& Kohler 1982, Maia et al. 2006, Wood et al. 2009, Preti et al. 2012), and mako sharks appear to be less dependent on the deep scattering layer than sympatric blue sharks (Preti et al. 2012). In addition, fine-scale resolution of depth data indicates that the deeper daytime distribution of mako sharks is the result of repetitive bounce diving to depths much greater than those typically observed during the nighttime, rather than following and remaining at the depth of the deep scattering layer. This bounce diving pattern has also been observed in mako sharks tracked in the Pacific (Sepulveda et al. 2004, Vetter et al. 2008, Abascal et al. 2011), and although it does not appear to be associated with foraging in the deep scattering layer specifically, it may still be associated with foraging. Sepulveda et al. (2004) observed that successful foraging events occurred primarily on deep daytime dives, suggesting that mako sharks rely heavily on vision to locate prey. Hypertrophy of the mesencephalon, which has been attributed to visual predation, has also been observed in the mako shark (Yopak et al. 2007, Yopak 2012), providing further support for the importance of vision in mako shark foraging. The diurnal deep bounce diving behavior may therefore arise from mako sharks searching for prey across depths where prey are easily visible.

Mako sharks in our study spent a great deal of time at temperatures higher than the reported preferred temperature range (i.e. $17-22^{\circ} \mathrm{C}_{i}$ Casey \& Kohler 1992). However, this preferred temperature range has been inferred primarily from commercial and recreational fishery catch records in the North Atlantic (Hoey 1983, Mejuto \& Iglesias 1988, Casey \& Kohler 1992). Although these fisheries-based records are for surface temperatures, electronic tag tracking studies 
from the eastern Pacific Ocean, which recorded the temperature of the water occupied by mako sharks, have also supported a preferred temperature range of 17 to $22^{\circ} \mathrm{C}$ (Holts \& Bedford 1993, Sepulveda et al. 2004, Abascal et al. 2011). Most information on mako shark temperature preference, however, is from cooler regions of their distribution, where waters typically do not exceed $22^{\circ} \mathrm{C}$. Mako sharks tracked in areas of warmer water (the Central Pacific: Musyl et al. 2011; the Gulf Stream: Loefer et al. 2005, this study; and the Gulf of Mexico: this study) spent substantial amounts of time in water warmer than $22^{\circ} \mathrm{C}$ and often exceeding $25^{\circ} \mathrm{C}$, demonstrating that mako sharks readily occupy waters $>22^{\circ} \mathrm{C}$ when available, and that the upper limit of the preferred temperature range has previously been underestimated.

Like other lamnids, mako sharks are regionally endothermic with visceral temperatures 6 to $8 \mathrm{C}^{\circ}$ warmer than ambient water temperature (Carey et al. 1981). The preference for warmer waters and limited time spent in cooler waters indicated by our results runs counter to expectations that endothermy in fishes allows expansion of the thermal niche and exploitation of cooler waters (Dickson \& Graham 2004, Weng et al. 2005, 2008, Campana et al. 2010). Further support that the primary role of endothermy in mako sharks may not be thermal niche expansion (i.e. increase their use of cooler waters) comes from comparisons to the sympatric, ectothermic blue shark. The vertical and thermal distributions of mako and blue sharks are generally similar (e.g. Carey \& Scharold 1990, Queiroz et al. 2010, Stevens et al. 2010), but diet data indicate that blue sharks are more dependent on prey from deeper and generally cooler depths (e.g. Preti et al. 2012). In addition, shark fishing tournament records show that in the US mid-Atlantic states, blue sharks dominated catches when surface temperatures were $<18^{\circ} \mathrm{C}$ and mako sharks became common at surface temperatures $\geq 18^{\circ} \mathrm{C}$ (Casey \& Kohler 1992).

While our data on the vertical and horizontal movements of mako sharks do not support endothermy as an adaptation for niche expansion into colder waters, it may have led to an increased trophic niche by providing other ecological and physiological benefits. In mako sharks, muscles should operate more efficiently and with more power at temperatures higher than ambient seawater, like in salmon sharks where endothermy results in a nearly 3 -fold increase in power production of white muscle (Bernal et al. 2005). This increased performance allows for comparatively higher cruising speeds, thus allowing greater prey encounter rates (Watanabe et al. 2015), and also specific targeting of active, nutritionally high-energy prey. Warming of the gut may also increase rates of digestion. At in vivo temperatures, digestive enzyme activities in mako sharks are $\sim 2$ to 27 times higher than that of the sympatric, ectothermic blue sharks and thresher sharks Alopias vulpinus (Newton et al. 2015). These physiological advantages have likely led to the separation of diets observed between these species (Preti et al. 2012) because they allow mako sharks to target more active and energy-rich prey. Such prey targeting by mako sharks has been observed in the western North Atlantic, where bluefish comprise $~ 90 \%$ of the mako shark diet by weight (Wood et al. 2009).

Overall, mako shark habitat use in the western North Atlantic Ocean is strongly associated with warmer temperature features, and we therefore hypothesize that temperature is the major environmental influence on the movement ecology of this species. In this region, temperatures between 10 and $15^{\circ} \mathrm{C}$ appear to represent the typical lower temperature limits of mako sharks, constraining not only their maximum depths, but also the northern extent of their range over the course of the year. The upper limits of the depth distribution also appear to be thermally dependent, with mako sharks avoiding waters $>27^{\circ} \mathrm{C}$. Within these thermal bounds, mako shark vertical movements follow a diel cycle, with individuals staying shallower during the nighttime and making deeper bounce dives during the daytime. Additionally, the large amount of fine-scale temperature data obtained in our study illustrate that mako sharks in the western North Atlantic spend more time in warmer water than previously reported, casting doubt that the primary function of endothermic physiology in this species is thermal niche expansion.

The strong association between mako shark habitat use and temperature also suggests that rising ocean temperatures may impact mako shark behaviors. Warming temperatures may lead to an expansion of the depths used as the lower thermal boundary deepens, but could also result in mako sharks spending less time at the surface. The timing and extent of migratory patterns may also change. For example, the waters off the northeastern USA will be accessible for a larger portion of the year, with temperatures increasing to acceptable levels earlier in the year and staying above these levels later into the winter. Waters farther to the north would also become accessible. These dynamics, however, might not be easy to predict because they are also dependent on how mako shark prey are affected by changing temperatures. Over long periods of time, warm- 
ing temperatures could even highly constrain mako shark movements. In the eastern North Pacific, rising temperatures are predicted to decrease core mako shark habitat by over $25 \%$ by 2100 (Hazen et al. 2013). As a result, knowledge of the relationship between temperature and mako shark physiology is crucial to understanding the behavior of this highly migratory and globally exploited shark.

Acknowledgements. This research was supported by the Florida Sea Grant Program (R/LR-B-73 to MSS), the Guy Harvey Ocean Foundation, the Shark Foundation, the Bluefish-Striped Bass Dynamics Research Program at Rutgers University in cooperation with the National Marine Fisheries Service (grant NA97FE0363) and Nova Southeastern University. We thank A. Mendillo, J. Captipovic, M. Managgio, G. Skomal, and A. Marcher for assistance in the field, M. Byrne for helpful suggestions on the manuscript, and Microwave Telemetry Inc., for the gift of 2 PSATs used in this study.

\section{LITERATURE CITED}

Abascal FJ, Quintans M, Ramos-Cartelle A, Mejuto J (2011) Movements and environmental preferences of the shortfin mako, Isurus oxyrinchus, in the southeastern Pacific Ocean. Mar Biol 158:1175-1184

> Bates D, Maechler M, Bolker B, Walker S (2015) Fitting linear mixed-effects models using lme4. J Stat Soft 67:1-48

> Baum JK, Blanchard W (2010) Inferring shark population trends from generalized linear mixed models of pelagic longline catch and effort data. Fish Res 102:229-239

> Baum JK, Myers RA, Kehler DG, Worm B, Harley SJ, Doherty PA (2003) Collapse and conservation of shark populations in the Northwest Atlantic. Science 299: 389-392

Bernal D, Donley JM, Shadwick RE, Syme DA (2005) Mammal-like muscles power swimming in a cold-water shark. Nature 437:1349-1352

> Beverly S, Curran D, Musyl M, Molony B (2009) Effects of eliminating shallow hooks from tuna longline sets on target and non-target species in the Hawaii-based pelagic tuna fishery. Fish Res 96:281-288

Block BA, Jonsen ID, Jorgensen SJ, Winship AJ and others (2011) Tracking apex marine predator movements in a dynamic ocean. Nature 475:86-90

Braun CD, Kaplan MB, Horodysky AZ, Llopiz JK (2015) Satellite telemetry reveals physical processes driving billfish behavior. Anim Biotelem 3:2

Cailliet GM, Cavanagh RD, Kulka DW, Stevens JD and others (2009) Isurus oxyrinchus. The IUCN Red List of Threatened Species. Version 2014.1

> Campana SE, Marks L, Joyce W (2005) The biology and fishery of shortfin mako sharks (Isurus oxyrinchus) in Atlantic Canadian waters. Fish Res 73:341-352

> Campana SE, Joyce W, Fowler M (2010) Subtropical pupping ground for a cold-water shark. Can J Fish Aquat Sci 67:769-773

Campana SE, Dorey A, Fowler M, Joyce W, Wang Z, Wright D, Yashayaev I (2011) Migration pathways, behavioural thermoregulation and overwintering grounds of blue sharks in the northwest Atlantic. PLoS ONE 6:e16854
Carey FG, Scharold JV (1990) Movements of blue sharks (Prionace glauca) in depth and course. Mar Biol 106: 329-342

Carey FG, Teal JM, Kanwisher JW (1981) The visceral temperatures of mackerel sharks (Lamnidae). Physiol Zool 54:334-344

- Casey JG, Kohler NE (1992) Tagging studies on the shortfin mako shark (Isurus oxyrinchus) in the western North Atlantic. Aust J Mar Freshw Res 43:45-60

> Clarke SC, McAllister MK, Milner-Gulland EJ, Kirkwood GP and others (2006) Global estimates of shark catches using trade records from commercial markets. Ecol Lett 9:1115-1126

Cliff G, Dudley SFJ, Davis B (1990) Sharks caught in the protective gill nets off Natal, South Africa. 3. The shortfin mako shark Isurus oxyrinchus (Rafinesque). S Afr J Mar Sci 9:115-126

> Cortés E (1999) Standardized diet compositions and trophic levels of sharks. ICES J Mar Sci 56:707-717

- Dewar H, Prince ED, Musyl MK, Brill RW and others (2011) Movements and behaviors of swordfish in the Atlantic and Pacific Oceans examined using pop-up satellite archival tags. Fish Oceanogr 20:219-241

> Dickson KA, Graham JB (2004) Evolution and consequences of endothermy in fishes. Physiol Biochem Zool 77: 998-1018

> Dulvy NK, Fowler SL, Musick JA, Cavanagh RD and others (2014) Extinction risk and conservation of the world's sharks and rays. eLife 3:e00590

> Ferretti F, Worm B, Britten GL, Heithaus MR, Lotze HK (2010) Patterns and ecosystem consequences of shark declines in the ocean. Ecol Lett 13:1055-1071

- Frid A, Burns J, Baker GC, Thorne RE (2009) Predicting synergistic effects of resources and predators on foraging decisions by juvenile Steller sea lions. Oecologia 158: 775-786

Galuardi B (2012) analyzepsat: functions for microwave telemetry PSAT analysis. R package version 3.1. https:// code.google.com/archive/p/analyzepsat/downloads

Garcia HE, Locarnini RA, Boyer TP, Antonov JI and others (2014) World ocean atlas 2013, Vol 3: dissolved oxygen, apparent oxygen utilization, and oxygen saturation. NOAA Atlas NESDIS 75, Department of Commerce, Silver Springs, MD

> Goodyear CP, Luo J, Prince ED, Hoolihan JP, Snodgrass D, Orbesen ES, Serafy JP (2008) Vertical habitat use of Atlantic blue marlin Makaira nigricans: interaction with pelagic longline gear. Mar Ecol Prog Ser 365:233-245

Hazen EL, Jorgensen S, Rykaczewski RR, Bograd SJ and others (2013) Predicted habitat shifts of Pacific top predators in a changing climate. Nat Clim Change 3:234-238

Heithaus MR, Frid A, Wirsing AJ, Worm B (2008) Predicting ecological consequences of marine top predator declines. Trends Ecol Evol 23:202-210

Heithaus MR, Frid A, Vaudo JJ, Worm B, Wirsing AJ (2010) Unraveling the ecological importance of elasmobranchs. In: Carrier JC, Musick JA, Heithaus MR (eds) Sharks and their relatives II: biodiversity, adaptive physiology, and conservation. CRC Press, Boca Raton, FL, p 611-637

Hoey JJ (1983) Analysis of longline fishing effort for apex predators (swordfish, shark, and tuna) in the western North Atlantic and Gulf of Mexico. PhD dissertation, University of Rhode Island, Kingston, RI

Holts DB, Bedford DW (1993) Horizontal and vertical movements of the shortfin mako shark, Isurus oxyrinchus, in 
the Southern California Bight. Aust J Mar Freshw Res 44: 901-909

Hothorn T, Bretz F, Westfall P (2008) Simultaneous inference in general parametric models. Biometric J 50:346-363

$>$ Klimley AP, Beavers SC, Curtis TH, Jorgensen SJ (2002) Movements and swimming behavior of three species of sharks in La Jolla Canyon, California. Environ Biol Fishes 63:117-135

Lam CH, Nielsen A, Sibert JR (2008) Improving light and temperature based geolocation by unscented Kalman filtering. Fish Res 91:15-25

Loefer JK, Sedberry GR, McGovern JC (2005) Vertical movements of a shortfin mako in the western North Atlantic as determined by pop-up satellite tagging. Southeast Nat 4:237-246

Maechler M, Rousseeuw P, Struyf A, Hubert M, Hornik K (2015) Cluster: cluster analysis basics and extensions. R package version 2.0.1. https://cran.r-project.org/web/ packages/cluster/index.html

Maia A, Queiroz N, Correia JP, Cabral H (2006) Food habits of the shortfin mako, Isurus oxyrinchus, off the southwest coast of Portugal. Environ Biol Fishes 77:157-167

Mejuto J, Iglesias S (1988) Compaña comercial de prospección de abundancia de pez espada, Xiphias gladius L., y especies asociadas, en areas próximas a Grand Banks. ICCAT Coll Vol Sci Paps 27:155-163

Musick JA, Branstetter S, Colvocoresses JA (1993) Trends in shark abundance from 1974 to 1991 for the Chesapeake Bight Region of the U.S. Mid-Atlantic coast. NOAA Tech Rep 115. National Marine Fisheries Service

Musyl MK, Brill RW, Curran DS, Fragoso NM and others (2011) Postrelease survival, vertical and horizontal movements, and thermal habitats of five species of pelagic sharks in the central Pacific Ocean. Fish Bull 109:341-368

Newton KC, Wraith J, Dickson KA (2015) Digestive enzyme activities are higher in the shortfin mako shark, Isurus oxyrinchus, than in ectothermic sharks as a result of visceral endothermy. Fish Physiol Biochem 41:887-898

Nielsen A, Sibert JR, Ancheta J, Galuardi B, Lam CH (2012) ukfsst: Kalman filter tracking including sea surface temperature. $\mathrm{R}$ package version 0.3. https://github.com/ positioning/kalmanfilter

Preti A, Soykan CU, Dewar H, Wells RJD, Spear N, Kohin S (2012) Comparative feeding ecology of shortfin mako, blue, and thresher sharks in the California Current. Environ Biol Fishes 95:127-146

Prince ED, Goodyear CP (2006) Hypoxia-based habitat compression of tropical pelagic fishes. Fish Oceanogr 15: 451-464

Queiroz N, Humphries NE, Noble LR, Santos AM, Sims DW (2010) Short-term movements and diving behaviour of satellite-tracked blue sharks Prionace glauca in the northeastern Atlantic Ocean. Mar Ecol Prog Ser 406:265-279

Rogers PJ, Huveneers C, Page B, Goldsworthy SD and others (2015) Living on the continental shelf edge: habitat use of juvenile shortfin makos Isurus oxyrinchus in the Great Australian Bight, southern Australia. Fish Oceanogr 24: 205-218

Editorial responsibility: Rory Wilson,

Swansea, UK
Schaefer KM, Fuller DW (2010) Vertical movements, behavior, and habitat of bigeye tuna (Thunnus obesus) in the equatorial eastern Pacific Ocean, ascertained from archival tag data. Mar Biol 157:2625-2642

Sepulveda CA, Kohin S, Chan C, Vetter R, Graham JB (2004) Movement patterns, depth preferences, and stomach temperatures of free-swimming juvenile mako sharks, Isurus oxyrinchus, in the Southern California Bight. Mar Biol 145:191-199

Speed CW, Field IC, Meekan MG, Bradshaw CJA (2010) Complexities of coastal shark movements and their implications for management. Mar Ecol Prog Ser 408: 275-293

Stevens JD, Bradford RW, West GJ (2010) Satellite tagging of blue sharks (Prionace glauca) and other pelagic sharks off eastern Australia: depth behaviour, temperature experience and movements. Mar Biol 157:575-591

Stillwell CE, Kohler NE (1982) Food, feeding habits, and estimates of daily ration of the shortfin mako (Isurus oxyrinchus) in the Northwest Atlantic. Can J Fish Aquat Sci 39:407-414

> Thorrold SR, Afonso P, Fontes J, Braun CD, Santos RS, Skomal GB, Berumen ML (2014) Extreme diving behaviour in devil rays links surface waters and the deep ocean. Nat Commun 5:4274

Vetter R, Kohin S, Preti A, McClatchie S, Dewar H (2008) Predatory interactions and niche overlap between mako shark, Isurus oxyrinchus, and jumbo squid, Dosidicus gigas, in the California Current. Calif Coop Ocean Fish Invest Rep 49:142-156

Walli A, Teo SLH, Boustany A, Farwell CJ and others (2009) Seasonal movements, aggregations and diving behavior of Atlantic bluefin tuna (Thunnus thynnus) revealed with archival tags. PLoS ONE 4:e6151

> Watanabe YY, Goldman KJ, Caselle JE, Chapman DD, Papastamatiou YP (2015) Comparative analyses of animal-tracking data reveal ecological significance of endothermy in fishes. Proc Natl Acad Sci USA 112:6104-6109

Weng KC, Castilho PC, Morrissette JM, Landeira-Fernandez AM and others (2005) Satellite tagging and cardiac physiology reveal niche expansion in salmon sharks. Science 310:104-106

> Weng KC, Foley DG, Ganong JE, Perle C, Shillinger GL, Block BA (2008) Migration of an upper trophic level predator, the salmon shark Lamna ditropis, between distant ecoregions. Mar Ecol Prog Ser 372:253-264

Wood AD, Wetherbee BM, Juanes F, Kohler NE, Wilga C (2009) Recalculated diet and daily ration of the shortfin mako (Isurus oxyrinchus), with a focus on quantifying predation on bluefish (Pomatomus saltatrix) in the northwest Atlantic Ocean. Fish Bull 107:76-88

Yopak KE (2012) Neuroecology of cartilaginous fishes: the functional implication of brain scaling. J Fish Biol 80: 1968-2023

> Yopak KE, Lisney TJ, Collin SP, Montgomery JC (2007) Variation in brain organization and cerebellar foliation in Chondrichthyes: sharks and holocephalans. Brain Behav Evol 69:280-300

Submitted: August 24, 2015; Accepted: February 1, 2016 Proofs received from author(s): March 24, 2016 